\title{
Conceptualizing Black Women's Employment Experiences
}

\author{
Cathy Scarborough
}

For me to think about racism and sexism meant I had to pull myself together and look at myself as one person under a law that separates me into my woman being and into my Black being.

\section{Kimberlé Grenshaw ${ }^{1}$}

Black women ${ }^{2}$ in America $^{3}$ have always been workers-as slaves, farmers, domestics, skilled and unskilled laborers, and even, in small numbers, as professionals. Their ability to find and retain jobs has usually been essential to the survival of their families. ${ }^{4}$ Despite their history of industriousness, Black women have found it impossible to escape racism and sexism in the job market. The very laws designed to eliminate employment discrimination have actually placed new obstacles in front of Black women. In order to challenge employment discrimination, Black women must use legal remedies and strategies that were designed for others. Whenever the legal system has attempted to deal with the problems Black women face in the workplace, it has consistently ignored their social history and failed to truly understand their experiences or address their concerns.

This Note attempts to provide an historical account of how the law has perceived and treated Black women. Title VII of the Givil Rights Act of $1964^{\circ}$ provides a framework for viewing the interaction between Black women and the law. Section I of this Note examines the experiences of Black women in America from slavery to the present in order to reveal why the experiences of Black women cannot be understood simply as a

1. Address by Professor Kimberlé Crenshaw, Women And The Law: A Feminist Jurisprudence (Apr. 2, 1986) [hereinafter Crenshaw].

2. I focus on the experiences of African-American women in the United States from slavery to the present. However, other people protected by Title VII of the Civil Rights Act of 1964, 42 U.S.C. $\S$ 2000 e-2(a) (1982), may also benefit from my proposal. See infra note 123 and accompanying text.

3. The term America in this paper means the United States of America.

4. See P. Giddings, When and Where I ENTER: The Impact of Black Women On Race AND SEX IN AMERICA 150-51 (1984).

5. Title VII makes it unlawful for an employer "to fail or refuse to hire or to discharge any individual, or otherwise to discriminate against any individual with respect to his compensation, terms, conditions, or privileges of employment, because of such individual's race, color, religion, sex, or national origin." 42 U.S.C. $\S 2000 \mathrm{e}-2$ (a) (1982). 
combination of Black men's and white women's experiences. It is necessary to study Black women's experiences in America in order to understand who they are and how to adequately address their concerns. Section II examines the legislative history of Title VII as it relates to the employment discrimination concerns of Black women. Section III analyzes how courts have dealt with the question of whether Black women can be considered a special class protected by Title VII. Finally, Section IV proposes methods that courts can use to adequately address the employment concerns of Black women-first, by understanding that Black women are not a subgroup of an ideal "main" group; second, by considering Black women's perspectives; third, by discarding the "sex-plus" rationale advocated in Jefferies v. Harris County Community Action Ass' $n^{6}$ and limited in Judge v. Marsh ${ }^{7}$ and lastly, by applying Title VII in a way that encompasses Black women's experiences in their entirety.

\section{Historical Experiences of Black Women in the UNITED STATES}

American society has long considered men more valuable than women, and whites more valuable than Blacks. ${ }^{8}$ In addition, Black women have not been viewed as a separate group with different concerns and experiences from both white women and Black men. The difficulties Black women face in the American legal system have their roots in a society that has historically avoided considering Black women as whole persons. Society has tended to use broader terms such as "Blacks" and "women," while really meaning Black men and white women, and thereby reinforcing the invisibility of Black women. ${ }^{9}$

Despite the marginalization of their experience in American society, Black women have played and continue to play an important and unique role. Yet, because their separate reality has been ignored, it has been difficult for courts and legislatures to devise appropriate legal means to deal with the composite effects of their "Blackness" and "womanness."

6. 615 F.2d 1025 (5th Cir. 1980).

7. 649 F. Supp. 770 (D.D.C. 1986).

8. The common historical belief was expressed in an editorial in a New York Herald newspaper: How did woman first become subject to man as she now is all over the world? By her nature, her sex, just as the negro is and always will be, to the end of time, inferior to the white race, and, therefore, doomed to subjection; but happier than she would be in any other condition, just because it is the law of her nature. The women themselves would not have this law reversed.

R. Ginsburg, Constrtutional aspects Of Sex-based Discrimination 2 (1974) (quoting A. Kraditor, Up From the Pedestal: Selected Writing in the History of America FemiNISM 190 (1968)).

9. "No other group in America has so had their identity socialized out of existence as have black women. . . . When black people are talked about, the focus tends to be on black men; and when women are talked about, the focus tends to be on white women." B. Hooks, ArN'T I A WoMan: Black Women and Feminism 7 (1981). 


\section{A. Black Women As Slave Workers}

Sojourner Truth once said that Black women suffered by having to work like men without the rights of men, while also having to deal with the agonies of being women with none of the privileges and advantages of white women. ${ }^{10}$ During slavery, Black men and Black women were treated as chattels by both federal and state legislatures and courts. ${ }^{11}$ The Constitution deprived slaves and white women of the right to vote, thereby perpetuating racism and sexism and protecting the power and property rights of those in control. ${ }^{12}$

In addition, Black women were exploited as only women in their position could be. ${ }^{13}$ They were viewed as reproductive servants. ${ }^{14}$ Black women, as slaves, could not bring legal claims alleging rape because they had no rights. ${ }^{15}$ Hamilton v. $\mathrm{Cragg}^{16}$ illustrates Black women's unique racial and sexual exploitation as a class of slaves. In that case, a Black woman sought to take her child, born to her when she was a slave, with her when she gained freedom. The court held that as a slave, she was Black chattel whose body "issues" and physical and sexual being belonged to her white owner. ${ }^{17}$

10. Quoted in M. Marable, How Capitalism Underdeveloped Black America 64 (1983).

11. D. Bell, Race, Racism and American Law 11 (1980) (citing K. Stampp, The Peculiar INSTITUTION 197-236 (1956)); see also Dred Scott v. Sanders, 60 U.S. (19 How.) 393 (1857) (Blacks are not citizens within meaning of Constitution). In pre-Civil War cases, Black men and Black women were the objects-the property in dispute-not the plaintiffs or defendants. D. BELl, supra, at $11-12$.

12. The "Founding Fathers" excluded Black slaves from citizenship, and even personhood, through the force of law. The Constitution established that persons bound in service were to be considered only as three-fifths of a person. U.S. ConsT. art. I, $\S 4$, cl. 3 . It also denied them the constitutional rights of free men. D. BELL, supra note 11, at 22-23. Black men and Black women were excluded from the constitution as slaves, and white women, who were thought to occupy a separate "feminine" sphere and were considered unequal to men, see supra note 8 , were also denied the vote by the Constitution's authors. D. BELL, supra at 11, 16; R. GinsBuRG, supra note 8 , at 2 .

13. See A. Davis, Women, Race and Class 6-7 (1981).

14. Id. Slave-masters minimized the importance of Black women's role as "mothers" and emphasized their role as breeders. L. Rodgers-Rose, THE Black Woman 18 (1980).

15. Black women were thought of as not being "rapable" because of how society viewed them. The white woman was "depicted as goddess rather than sinner; she was virtuous, pure, innocent, not sexual and worldly," B. Hooks, supra note 9, at 31, while the "predominant image lof the Black woman was] that of the "fallen" woman, the whore, the slut, the prostitute." Id. at 52 . Even today, "Black women['s] . . . unique position in American history and mythology . . . makes them extremely vulnerable to sexual harassment on the job. The mythology and stereotypes, which at one time made Black women unrapable, continue to affect their job opportunities." Black women are still thought of as more sexually available "[a]nd more promiscuous than White women." Ellis, Sexual Harrassment and Race: A Legal Analysis of Discrimination, 8 J. LEGis. 30, 39 (1981).

16. $6 \mathrm{H}$ \& J 16 (Md. 1823) (cited in J. Wheeler, A Practical Treatise on the law of SLAVERY 26 (1837)).

17. The child born to the Black woman while she was as a slave was deemed to be a product belonging to the slave owner. Id. at 26 . The court held in Hamilton that, as a slave:

she had no civil rights, and could have pursued no legal remedy against her mistress on any account ... and was subject to all the disabilities and incapacities incident to a state of slavery. She was a mere chattel, the property of her mistress, who could have sold or transferred her at pleasure.

Hamilton, $6 \mathrm{H} \mathrm{\&} \mathrm{J} \mathrm{at} 17$.

As Manning Marable states, Black women, as slaves, were white people's property, and "[a]s prop- 


\section{B. Black Women As "Free" Workers}

As "free" workers after Emancipation, Black women as a class continued to suffer the burden of race-sex discrimination. The courts reinforced the societal invisibility of Black women by referring to women exclusively in stereotypical terms of white women's experiences. In Bradwell $v$. State, ${ }^{18}$ which allowed states to prohibit women from practicing law, Justice Bradley wrote in his concurrence that " $[t]$ he natural and proper timidity and delicacy which belongs to the female sex evidently unfits it for many of the occupations of civil life. . . The paramount destiny and mission of woman are to fulfill the noble and benign office of wife and mother. This is the law of the Creator." 19 This stereotypical depiction of white womanhood ${ }^{20}$ contrasts sharply with Black women's experiences, since Black women were in no way considered timid or delicate. ${ }^{21}$ The Court's words lie in sharp contrast to the resonating challenge of Sojourner Truth:

Nobody ever helped me into carriages, or over mud puddles, or give $m e$ any best place! And ain't I a woman? Look at me, look at my arm! I have plowed, and planted, and gathered into barns-and no man could head me - and ain't I a woman? I have born'd five children and seen'em most all sold off into slavery, and when I cried out with a mother's grief, none but Jesus heard ... and ain't $I$ a woman? ?2 $^{22}$

After slavery, Black women had to deal with economic hardship. ${ }^{23}$ The

erty, Black women were expected to produce wealth for their owners. But as females, Black women were also constantly subjected to the physical and sexual assault of white males. . . For the white male American, the Black woman's vagina was his private property." M. MARABLE, supra note 10, at $72-73$.

18. 83 U.S. (16 Wall.) 130 (1872).

19. Id. at 141 .

20. It is doubtful that the Bradwell Court accurately described the reality even of most white women's experiences. See generally A. DAvis, supra note 13, at 228-29 (describing experiences of working class white women and development of "universal" vision of "womanhood").

21. See A. Davis, supra note 13, at 7-8; J. JONEs, LABOR OF LOVE, LABOR of Sorrow: Black Women, Work, and the Family from Slavery to the Present 58-59 (1985); Palmer, White Women / Black Women: The Dualism of Female Identity and Experience in the United States, 9 Feminist Studies 151, 153 (1983).

22. Quoted in M. MARABLE, supra note 10, at 69. In Muller v. Oregon, 208 U.S. 412 (1908), the Court continued to follow Bradwell's sanctioning of differential treatment of men and women based upon a stereotypical vision of white womanhood. The Court ruled that an Oregon employment statute which prohibited women from being employed in any mechanical establishment, factory, or laundry for more than 10 hours a day was constitutional. Id. at 416. The Court justified its decision by stating that "[t]he two sexes differ in structure of body, in the functions to be performed by each, in the amount of physical strength, in the capacity for long-continued labor, particularly when done standing. . . ." Id. at 422 . The Court believed that women were dependent upon men and that they needed to be protected from the greed and passion of men. A woman's place was in the home, fulfilling her maternal function and thereby safeguarding the wellbeing of the race. Once again, the Court's understanding of the condition of "women" clearly did not reflect Black women's experiences in the United States.

23. L. RoDgers-Rose, supra note 14 , at 22. 
majority of Black women in the early 1900 s were still working on farms, taking care of white people's homes, ${ }^{24}$ or employed as unskilled service laborers. ${ }^{25}$ The jobs held by Black women often required them to work well over ten hours per day, even though they may have had children at home or been pregnant. Thus, the Court clearly did not consider Black women in developing its myth of womanhood. Although the term "women" was used in a broad and inclusive manner, the emphasis on the weak physical structure of women and their place in society ignored Black women's historical experiences and contributions.

During World War I, when Black women were allowed to enter into manufacturing and mechanical jobs in limited numbers, ${ }^{26}$ unlike their white sisters, who were viewed as being "timid" and "delicate," they were made to perform the most difficult and the dirtiest jobs. ${ }^{27}$ Yet, the courts failed to acknowledge the existence of any image of womanhood other than that which they perceived to be experienced by white women, ignoring the reality of the concerns and experiences of many women.

\section{Recent History}

The Civil Rights Movement of the 1950s and 1960s also ignored Black women's separate concerns. ${ }^{28}$ The focus and concern of both Black men and Black women was to end the racist segregationist practices that existed in America. ${ }^{28}$ The Movement led to the enactment of statutes and administrative practices prohibiting race discrimination..$^{30}$ These statutes, which included Title VII, gave Black men and Black women the right to challenge race discrimination in the courts. However, the unique problems Black women faced as a class were not addressed in the new legislation, nor in the cases which followed. ${ }^{31}$ Male members of the Black Power Movement, which grew out of the Civil Rights Movement in the late

24. Terborg-Penn, Survival Strategies Among African-American Women Workers: A Continuing Process, in Women, Work and Protest: A CENTURy of U.S. Labor History (R. Milkman ed. 1985).

25. J. Jones, supra note 21 , at 155-58; S. Harkey \& R. Terborg-Penn, The AfroAMerican Woman: Struggles and IMAges 10 (1979); L. Rodgers-Rose, supra note 14, at 23.

26. S. HARKEY \& R. Terborg-PenN, supra note 25 , at 7.

27. P. GidDings, supra note 4, at 144 ("The historical stereotypes assigned to Black women were largely responsible for this. For example, because they were thought to be able to withstand more heat, they got the most heat-intense jobs."). However, it was not until World War II that Black women were allowed to work in factories in any significant numbers. Id. Once again, when Black women entered these jobs they were paid less than white women for doing the same or a harder job and were required to work in worse conditions than white women. B. Hooks, supra note 9, at 135. For example, Black women were hired to clean, sweep, and fill the hardest and most unpleasant positions, while others used the machines and held supervisory positions. Terborg-Penn, supra note 24 , at 147.

28. M. MARABLE, supra note 10, at 99 ("In theory and practice, the Black protest movement was compromised and gutted by its inability to confront squarely the reality of patriarchy.")

29. P. GiddinGs, supra note 4 , at 302 .

30. C. \& B. Whalen, The Longest Debate: A Legislative History of the 1964 Givil. Rights ACT 222-38 (1983); M. MARABLE, supra note 10, at 99.

31. See infra Sections II \& III. 
1960s, presumed that if the Black man advanced, so would the Black woman. ${ }^{32}$ Many were only concerned that Black men regain their manhood. ${ }^{33}$

Furthermore, Black women were blamed for the poverty and "backwardness" of the Black race, as evidenced by the conclusions of the Moynihan Report. ${ }^{34}$ The Moynihan Report, which reflected American society's patriarchal underpinnings, described Black women as matriarchal figures, incapable of caring for their children and responsible for producing male children unable to deal with the world because they had been weakened by their domineering mothers. ${ }^{35}$ The report proposed that Black society mimic the sexual hierarchy of white middle-class society in order to improve its conditions. ${ }^{38}$ The report focused on the problems of Black males and paid little attention to Black females. ${ }^{37}$ Black women remained invisible, except as a focus for blame.

The Supreme Court's review of women's history in Frontiero v. Rich$\operatorname{ardson}^{38}$ illustrates contemporary courts' lack of awareness of Black women. Justice Brennan, writing for the plurality, addressed the "long and unfortunate history of sex discrimination"39 in the United States and acknowledged that this discrimination "was rationalized by an attitude of

32. Male pride became the focus, and Black men demanded that Black women support them and stop being "bossy" and "pushy." See B. Hooks, supra note 9, at 85; M. Marable, supra note 10, at 85. Paula Giddings agrees that "a male-conscious motif ran throughout the society . . . ." P. GIDDiNGs, supra note 4 , at 314. Kathleen Cleaver, a Black Panther Party officer, said that her views were often ignored because she was a woman: "[I]f I suggested [ideas], the suggestion might be rejected; if they were suggested by a man the suggestion would be implemented." Id. at 317. Angela Davis similarly observes, "I was criticized very heavily especially by male members of (Ron) Karenga's (U.S.) organization for doing a "man's job'." Id. at 316. The male perspective is reflected in the remarks of several of the movement's leaders. Floyd McKissic of Congress Of Racial Equality (CORE) stated that in "[t]he year 1966 . . . we left our imposed status as Negroes, and became Black Men." Id. at 315. Stokley Carmichael stated that "in the coming racial war Black People would stand on our feet and die like men, if that's our only act of manhood." Id. Similarly, the women's movement, which began in the late 1960s, failed to include Black women. "[I]t was evident that the White women who dominated the movement felt it was 'their' movement, that is, the medium through which a white woman would voice her grievances to society," as opposed to an organization created for all women to voice their grievances. B. Hooks, supra note 9, at 136-37.

33. ReId, Black Women's Struggle For Equality 3 (1976).

34. Office of Policy Planning and Research, United States Department of Labor, the Case for National Action-The Negro FamiLy, 29, 34 (1985) [hereinafter MoynihaN REPORT]. According to this report "negro children without fathers flounder and fail," unlike White children who see the pattern of men working all around them. Id. at 1,35 .

35. Id.

36. Id. at 5,45 .

37. The report said nothing about the employment discrimination experienced by Black women, nor did it cite the unemployment rate of Black women: It was, instead, concerned with their divorce rates, the number of illegitimate children they had, and the allegedly negative effect of the Black matriarchal structure on the Black family. The report found fault with the fact that almost as many Black men as Black women attended college, compared to the white ratio in which men clearly outnumbered women, and the fact that more Black women were working than Black men. Id. at 31-32. No reference was made to the fact that Black women were paid less than both Black men and white women. See id. at 33. This report did not seek to understand the separate concerns of the Black woman or attempt to devise policies that would empower her to help uplift the race.

38. 411 U.S. 677 (1973).

39. Id. at 684 . 
'romantic paternalism," " which placed "women" upon a pedestal that turned out to be no more than a paternalistic cage. ${ }^{40}$ Ignoring Black women's history, the opinion also viewed "Blacks" as a uniform group and observed that Blacks had gotten the right to vote-before women. ${ }^{41}$ The Court saw only two categories: Black men, who had the right to vote, and white women, who were imprisoned in a paternalistic cage. Where do Black women fit into this picture? The Court's failure to recognize and articulate the unique experiences of Black women as workers, slave breeders, and "unrapable"42 women, whose womanhood has continuously been devalued by American society, ${ }^{48}$ led it to project the experiences of one class of women onto all women.

\section{Current Problems of Black Women}

Black women's problems have not vanished. Currently, the effects of racism-sexism limit the opportunities of most Black women. Although Black women have begun to occupy jobs similar to those held by white women, they still fill the least prestigious and lowest paying jobs within that sector, and fill them in far smaller numbers than white women. ${ }^{44}$ Black women find that employers discriminate against them in pay and promotions, even though those same employers may not discriminate against Black men or white women. ${ }^{45}$

Historically, the unemployment rate for Black people has always been higher than the rate for white people. ${ }^{46}$ As of 1986 , Black women had an unemployment rate of $14.2 \%$, compared with $14.8 \%$ for Black men. ${ }^{47}$ The

\section{Id.}

41. Id. at 685 .

42. See supra note 15.

43. B. Hooks, supra note 8 , at $51-86$.

44. See Haywood, Can Theories Of Intentional Wage Discrimination And Comparable Worth Help Black People?, 10 NAT'L BLACK L.J. 16, 18-19 (1987).

45. Id. at 27. See also Jefferies v. Harris County Community Action Ass'n, 615 F.2d 1025 (5th Cir. 1980) (discrimination against Black women can exist even in absence of discrimination against Black men or white women).

46. For the unemployment rates of Black women, Black men, white women, and white men for the years 1950-1970, see U.S. Department of COMmerce, U.S. BuREAU of Census, Historical Statistics of THE U.S.: Colonial Times to 1970, table 2, at 84 (1972). For the years 1975-1985, see U.S. Department of Commerce, U.S. Bureau of Census, Statistical Abstract (1986).

47. U.S. Department of Commerce, Statistical Abstract of The United States 1988: No. 611, at 368 (108th ed. 1988) (citing figures from U.S. BUREAU of LABOR STATISTICs, EMPLOYMENT AND EARNINGS) [hereinafter UNEMPLOYMENT REPORT]; see generally U.S. DEPARTMENT OF Commerce, U.S. Bureau of Census-Historical Statistics of the U.S: Colonial Times to 1970: D 87-101 Series, at 134 (historical data).

The unemployment rate for Black women has always been comparable to that of Black men. Hooks argues that historically, Black men have sometimes had a slightly higher rate of unemployment than Black women because "even if white people had been eager to hire Black men in service jobs to work as maids and washermen, such jobs would have been refused because they would have been regarded as an assault on male dignity." B. Hooks, supra note 9, at 80 . While these unemployment rates have shifted back and forth, the "illusion that Black women ... had achieved parity or had exceeded Black men's earnings was not simply false, but a gross reversal of economic reality." M. MARABLE, supra note 10 , at 102 . Jones similarly concludes that "[t]he vast majority of black women employees 
unemployment rate of Black people remains disproportionately high when compared with the rates for white men and white women, which were $6.0 \%$, and $6.1 \%$, respectively. ${ }^{48}$

In addition, Black women as a group have always received the lowest income as year-round, full-time workers when compared to Black and white men and white women. ${ }^{49}$ The median earnings of Black women working full-time in 1986 was $\$ 12,126$ annually, while white women received $\$ 13,961$. Black and white male year-round, full-time workers received incomes of $\$ 15,125$ and $\$ 22,390$, respectively. ${ }^{\text {so }}$

Some researchers ${ }^{51}$ state that, in some settings, the wages of Black women have recently been approaching those of white women ${ }^{52}$ because Black women are employed primarily in occupations which are viewed as "typically female jobs." even "within occupational categories . . . there are differences in the status of Black and white women," 54 for Black women occupy different enclaves of jobs which are typically female jobs. Failure to understand the interaction of racism and sexism in Black women's lives has led to society's non-recognition of what Malveaux terms "Black women crowding." ${ }^{\text {" }}$ Malveaux observes that "proportionately fewer Black than white women work in management, sales, and professional jobs, while proportionately more Black women work in service, operative (manufacturing), and private household jobs." ${ }^{.58}$ The jobs into which Black women are

at the lower echelons of the work force find employers eager to exploit their labor, because that labor is cheap and easily routinized." J. JonEs, supra note 21 , at 325 . But racism and sexism still deprive Black women of a living salary, no matter how hard they work. Id. at 199, 383 n.15-17.

48. UNEMPLOYMENT REPORT, supra note 47.

49. See U.S. Department of Commerce, Bureau of Census, Consumer Income Money Income of Families and Persons in the United States: 1981 Series P-60, No. 137, at 120-22.

50. Id.

51. See generally Albelda, "Nice Work If You Can Get It": Segmentation of White and Black Women Workers in the Post-War Period, 17 Rev. Radical. Pol. Econ. 72 (1985).

52. Consumer Income Money Income of Families and Person in the United States: 1986 SERIES P-60 No. 159, at 162.

53. This broad term has been used to define jobs into which most "women" are disproportionately concentrated. Malveaux \& Wallace, Minority Women in the Workplace, in WorkIng Women: Past-Present-Future 265, 279 (K. Koziara, M. Moskow \& L. Tanner eds. 1987)

54. Malveaux, Comparable Worth and Its Impact on Black Women, in SLIPPING Through THE CRACKs 53 (M. Simms \& J. Malveaux eds. 1985).

55. Professor Malveaux created the term "black women crowding" to describe the racial-gender crowding of Black women into "typical black female" jobs. Malveaux, supra note 54, at 54. Black women are concentrated in female service and clerical occupations, and even within these job sectors, they are segregated into the lowest pay and lowest status jobs. Id. at 53. Professor Williams defines this phenomenon occurance as the "intra-gender racial crowding of black women." $\mathrm{R}$. Williams, Beyond Human Capital: Black Women, Work And Wage-Working Paper No. 183, at 4. (Mar. 1988) (unpublished work available at Wellesley College Center for Research on Women).

56. Id. at 53 (citations omitted). For example, Black women are not overrepresented as bank tellers, secretaries/receptionists, and other occupations which are more than $95 \%$ female. Malveaux \& Wallace, supra note 53 , at 278 . Within each occupational category there is a difference in the status of white and Black women. Black women are, for the most part, crowded into the lowest clerical positions-typists, file clerks, key punch operators, calculating machine operators-and service positions-chambermaids, nurses aids and practical nurses. Id. 
crowded command less prestige and pay than those of white women ${ }^{57}$ and cast doubt on the supposed convergence of the wages of Black women towards those of white women. ${ }^{58} \mathrm{It}$ is, therefore, not surprising that Black women, as individuals, continue to suffer the highest poverty rate. As of $1986,34.5 \%$ of Black women lived in poverty, compared to $27.3 \%$ of Black men. White men and women had a poverty rate of only $12.3 \%$ and $9.6 \%$, respectively. ${ }^{58}$

As these statistics indicate, Black women remain at the bottom of the economy.$^{60}$ In order to help alleviate some of the particular problems Black women face, methods must be developed that address their historical experiences and current social status.

\section{The Legislative History of Title VII and Black Women}

\section{A. Congressional Response}

Congressional concern with the problems experienced by Black women in America had little influence on the development and language of Title VII. Despite an awareness of the problems faced by Black women expressed by a few members of Congress, other legislators thought that these problems would be addressed by the race provision. ${ }^{61}$

During the debates on Title VII, the House of Representatives did not consider the problem of sex discrimination until Representative Smith, an opponent of the measure, proposed that "sex" be added to the language of the bill. ${ }^{62} \mathrm{He}$ hoped to make the bill so controversial that neither the House nor the Senate would pass it. ${ }^{63}$

To counter Smith's surprise attack, Representative Green opposed the inclusion of "sex" in the bill. ${ }^{\text {o4 }}$ She believed that a Black woman, when

\section{Id. \\ 58. Id.}

59. U.S. Department of Commerce, Bureau of the Census, Poverty IN The United States 1986, Series P-60, No. 160, at 30 . Although all female heads of households face high poverty rates, Black women have the highest. Black women heads of household with no husband present experience a poverty rate $14.6 \%$ greater than white women's rate. Black women heads of household with no husband present had a $51.7 \%$ poverty rate as of 1984 , compared to $27.1 \%$ for similarly situated white women. Male heads of household with no wife present are, however, much better off. Black men in these circumstances showed a poverty rate of $23.8 \%$, compared to $10.4 \%$ for white men. U.S. Dept of Commerce, U.S. Bureau of the Gensus, Statistical Abstract of the U.S. Bureau of the Census, 1985, Current Population Reports Series P-60, No.146.

60. Professor Ellis' 1978 statement still defines the position of Black women today: "[Taken] all together, these statistics portray a situation of despair and economic vulnerability. They indicate that Black women are largely looking for work or employed in marginal jobs, earning low wages. At the same time Black women are very often the sole supporter of the family." Ellis, supra note 15, at 30 .

61. See infra notes 64-67 and accompanying text.

62. 110 Cong. Rec. 2577 (1964); C. \& B. Whalen, supra note 30, at 115-16; Scales-Trent, Black Women and the Constitution: Finding Our Place, Asserting Our Rights, 24 HARv. C.R.-C.L. L. REv. 9, 10-11 (1989); Shoben, Compound Discrimination: The Interaction of Race and Sex in Employment Discrimination, 55 N.Y.U. L. REv. 793, 796, 797 (1980).

63. C. \& B. WHALEN, supra note 30 , at 116 .

64. See, e.g., 110 CoNG. REC. 2721 (1964) ("Let us not further weaken . . . any section of the bill but rather let us by our votes make it abundantly clear that this Congress intends to have the 
compared to a white woman, "has suffered 10 times that amount of discrimination. She has a double discrimination. She was born as a woman and she was born as a Negro."68 Therefore, white women should wait for other legislation to advance their cause. ${ }^{66}$ Green believed that the aim of the legislation, providing Blacks with jobs and decent wages, would be undermined by irrelevant amendments. ${ }^{67}$ In contrast, Representative Bolton pushed the House to address the problems faced by women as a group. She thought that including "sex" in the statute would help all women. ${ }^{68}$

Despite this recognition of Black women's situation, by at least two representatives, there was some discussion that the bill was necessary to protect the rights of white women against Black women. Representative Griffiths argued that white men, in their unwillingness to include "sex" in the statute, were once again putting white women in the same disadvantageous position ${ }^{69}$ that they had during Reconstruction on the issue of extending voting rights. ${ }^{\mathbf{7 0}}$ She felt that the new bill, without the word "sex," would provide Black women with a remedy and give white women nothing. ${ }^{71}$ Others shared this concern. ${ }^{72}$

\section{B. Ambiguities in the Statutory Language}

In addition to the dispute over the inclusion of "sex," Representative Dowdy sought to have the word "solely" placed into the bill in order to establish that "any discrimination proscribed in the bill must be based solely on race, color, religion, sex or national origin." ${ }^{\text {"73 }}$ It has been suggested that the House's failure to pass the Dowdy proposal indicates that

Federal Government exercise its power in ending discrimination against Negroes wherever it is humanly possible.").

65. Id. at 2581-82.

66. For all of her insight into Black women's plight, Representative Green nevertheless neglected to see that the race provison standing alone would not fully address Black women's problems.

67. She felt that "[i]n offering amendments in regard to sex ... . [and] in trying to picture this legislation as the Negro woman against the white woman," the passage of the legislation was being jeopardized. Id. at 2721.

68. Bolton had the insight to recognize that for "this amendment to include sex as one of the grounds on which there shall be no discrimination affects very deeply Negro women who, perhaps, are at the small end of the horn in a great many of these areas." Id. at 2720.

69. Id. at 2580 .

70. A. DAvis, supra note 13 , at 114-15.

71. Griffths argued that if an employer had only white male employees, and a Black woman and white woman applied for the same job and were both rejected, then only the white woman, would lack a remedy. This new law would place "white men in one bracket, [and] . . . take colored men and colored women and give them equal employment rights," leaving white women "at the bottom of the list ... . with no rights at all." Id. at 2579.

72. See, e.g., id. at 2584 (statement of Representative Gatherings) ("There can be no plausible reason that a white woman should be deprived of an equal opportunity to get a job simply because of her sex and a colored woman obtain that position because of her preferential rights as contained in this bill."). Representative Andrews also supported the inclusion of "sex" in the bill. He felt that "[u]nless this amendment is adopted, the white women of this country would be drastically discriminated against in favor of a Negro woman." Id. at 2583.

73. Id. at 2728 (emphasis added). 
the "or" in the statute should be considered as an additive term rather than as an exclusive one. ${ }^{74}$ If "or" were interpreted inclusively, it would mean that the statute would allow suits and protected class status under Title VII to be based on more than one of the listed characteristics; ${ }^{75}$ conversely, interpreting the "or" as exclusive would mean that only one of the protected categories could be used by a plaintiff in an employment discrimination case. ${ }^{76}$ However, Congress' subsequent failure to incorporate the word "solely" into the final statute is inconclusive. This fact, standing alone does not provide enough information for determining the circumstances and form of claims that may be brought, under Title VII, by those who are the victims of discrimination on the basis of several protected characteristics.

Although Black women were discussed in the Congressional debates leading to the passage of Title VII, the legislative history of the Act does not provide an established policy or even a guideline for addressing their problems. The inconclusiveness of the legislative history also means that courts are not prohibited from developing strategies that fully address Black women's claims and that fulfill the aims and purposes of the statute. ${ }^{77}$ Courts should not merely look at particular clauses in a statute, but should also take into consideration the whole statute, including Congressional aims, as reflected by the statute's language, in order to implement the law in accordance with its true meaning and intent. ${ }^{78}$

\section{Current Judicial Treatment of Black Women's Title VII Claims}

Despite the lack of legislative guidance, Black women brought employment discrimination claims under Title VII based upon both race and sex. When confronted with these claims, many courts did not know how to address the issues involved.9

74. This amendment was also proposed in the Senate by Senator McClellan. See 110 CoNG. Rec. 13,837 (1964). It was defeated by a rule call. Id. at 13,838. Although Black women were not discussed at length in the Senate debates, Senator Humphrey's statement that Title VII was designed to help both Black men and women may also be an indication that the "or" is inclusive. 110 CoNG. REC. 6547. See Oldham, Questions of Exclusion and Exception Under Title VII-"Sex-Plus" and the BFOQ, 23 HASTINGS L.J. 55, 61 (1971).

75. See Jefferies v. Harris County Community Action Ass'n, 615 F.2d 1025, 1032 (5th Cir. 1980); infra notes 91-94 and accompanying text.

76. See Degraffenreid v. General Motors Assembly Dir., 413 F.Supp. 142, 143 (E.D. Miss. 1976), affd in part, rev'd in part, and remanded on other grounds, 558 F.2d 480 (5th Cir, 1977); see also infra text accompanying notes 82-86.

77. See infra Section IV(A).

78. See Brown v. Duchesne, U.S. (19 How.) 183, 194 (1857) (establishing approach for statutory construction); infra notes $114-116$ and accompanying text.

79. In many Title VII cases brought by Black women in the 1970 s, the issue of whether Black women were a class under Title VII was simply not addressed. In Miller v. Bank of Am., 600 F.2d 211, 212 (9th Cir. 1979), for example, the plaintiff alleged that her employment was unlawfully terminated because of her refusal to grant sexual favors to her supervisor, who wanted to have a good time with a "black chick"; the court allowed the sex claim, but dismissed the race claim. See also 


\section{A. The Separate Approach: Race or Sex}

Degraffenreid v. General Motors Assembly Division ${ }^{80}$ was the first case to consider whether Black women were a protected class under Title VII. In this 1976 case, the plaintiff, a Black woman, brought a combined race and sex discrimination claim alleging that her employer's "last hired-first fired" layoff policy discriminated against Black women and perpetuated past discriminatory practices. ${ }^{81}$

The Degraffenreid court addressed the plaintiff's race and sex discrimination claims separately, viewing them as two distinct and separate causes of action. The court feared that deciding a Black woman's claim based upon the interaction of race and sex would create a "super remedy" for Black women that "would give them relief beyond what the drafters of the relevant statutes intended." nate Black women as a "special class." not be treated any differently from white women or Black men. They must choose to bring either a race action or a sex action in order to avoid the creation of an unauthorized class which would give Black women greater standing and relief. ${ }^{84}$ In addition, the court insisted that allowing Black women to combine their claims and create a new class "clearly raises the prospect of opening the hackneyed Pandora's box," Title VII unmanageable, since members of other groups then could bring their own individual claims of "special" discrimination. ${ }^{86}$

The absurdity of the position taken by the Degraffenreid court becomes apparent upon examination of the analysis used to evaluate claims brought by other groups. Courts have never divided white women into whites and women, or Black men into Blacks and men. Their claims have not been treated as divided because the term "Blacks" has been understood to mean Black men, and "women" to mean white women. ${ }^{87}$

The Degraffenreid court did not see Black women as complete persons,

Munford v. James T. Barnes \& Co., 441 F.Supp. 459 (E.D. Mich. 1977) (dismissing plaintiffs race discrimination claim and allowing sex discrimination claim to stand). Other institutions have also been limited in their ability to address Black women's concerns. See Barnes v. Costle, 561 F.2d 983 (D.C. Cir. 1977) (EEOC officer misled plaintiff into bringing gender claim only).

Some courts found causes of action for Black women alleging sex and race claims. Yet, these courts did not state whether Black women are a protected class under Title VII, nor did they explain their analytic approach to Black women's claims. See Vuyanich v. Republic Bank of Dallas, 409 F. Supp. 1083,1089 (N.D. Tex. 1976) (termination of Black woman's employment "smacks of sexual as well as racial discrimination"); Logan v. St. Luke's Hosp., 428 F. Supp. 127 (S.D.N.Y. 1977) (Black woman allowed to bring race and sex claim); see also Ellis, supra note 15, at 70 (discussing how these courts dealt with Black women's claims).

80. 413 F. Supp. 142 (E.D. Miss. 1976).

81. Id. at 143 .

82. Id.

83. Id.

84. Id.

85. Id. at 145 .

86. Id.

87. See supra note 9. 
protected as a class under Title VII because it did not grasp the fact that all people have both a race and a gender, regardless of whether white women or Black men allege both of these factors in their claims. Black women could not fit into the Degraffenreid court's analysis because, as Professor Crenshaw explains, Black women are two steps removed from the legal norm, which "is not neutral but is white male."

\section{B. Sex Plus: An Attempt to Account for Black Women}

In Jefferies v. Harris Community Action Ass' $n{ }^{89}$ the Fifth Circuit rejected the Degraffenreid approach. Analogizing the race-sex discrimination faced by Black women to "sex-plus" discrimination," the court struck down the district court's order forcing the plaintiff, a Black woman,

88. Crenshaw, supra note 1, at 30; Minow, The Supreme Court 1986 Term-Foreword: Justice Engendered, 101 HaRv. L. REv. 1, 13 (1987).

89. 615 F.2d 1025 (5th Cir. 1980)

90. "Sex-plus" analysis is applied to situations where an employer discriminates against an employee on the basis of her/his sex and some additional characteristic or factor related to her/his sex. B. Schlet \& P. Grossman, Employment Discrimination Law 403 (2d ed. 1983). The sex-plus theory was created by the dissent in Phillips v. Martin Marietta Corp., 416 F.2d 1257 (5th Cir. 1969), rev'd, 400 U.S. 542 (1971) (Brown, J., dissenting), a case in which an employer refused to hire mothers, but not fathers, of pre-school-aged children. The employer tried to add a non-protected factor (parenthood of pre-school-aged children) to a protected factor (sex) in order to escape liability under Title VII. Thus, the employer's rule applied only to a subset of women with children. The Supreme Court reversed, holding that the plaintiff would have been hired but for her sex. 400 U.S. at 544. Sex-plus has also been applied to cases in which airline companies placed certain restrictions upon female flight attendants that did not apply to males. See Laffey v. Northwest Airlines, Inc., 507 F.2d 429, 456 (D.C. Cir. 1976), cert. denied, 434 U.S. 1086 (1978) (employer's policy enforced only against female stewardesses held to violate Title VII); Sprogis v. United Airlines, Inc., 444 F.2d 1194, 1198 (7th Cir. 1971), cert. denied, 404 U.S. 991 (employer's rule discriminating against married women violates Title VII); Binder, Sex Discrimination in the Airline Industry: Title VII Flying High, 59 Cal.If. L. Rev. 1091 (1971).

In order to prove a disparate treatment sex-plus discrimination claim, a plaintiff is required to show, under a disparate treatment test, that $\mathrm{s} / \mathrm{he}$ was intentionally discriminated against because of her/his sex and some additional factor. Phillips v. Martin Marietta Corp., 400 U.S. 542 (1971), rev'g 411 F.2d 1 (5th Cir. 1969). In a disparate impact sex-plus claim, a plaintiff must show that an employer's practices had an adverse impact upon those of his or her gender who also share a common characteristic or plus factor. Dothard v. Rawlinson, 433 U.S. 321 (1977). However, if the practice or policy that affects a sex-plus group is reasonably necessary to the normal operation of that particular business or enterprise, a bona fide occupational qualification (BFOQ) exemption may be granted by a court in disparate treatment cases. Section 703(e)(1) of Title VII states:

[I]t shall not be an unlawful employment practice for an employer to hire and employ employ-

ees on the basis of his religion, sex, or national origin in those certain instances where religion,

sex, national origin is a bona fide occupational qualification reasonably necessary to the nor-

mal operation of that particular business or enterprise.

$B F O Q$ defenses are limited to disparate treatment cases because only in that sort of case is there an admission by an employer that s/he is intentionally using a prohibited Title VII classification as a BFOQ. R. Richards, C. Sullivan \& M. Zimmer, Employment Discrimination 106 (2d ed. 1988). Most courts, however, allow limited scope to the BFOQ exemption. For example, sex would be a valid $B F O Q$ for the job of a wet nurse. Some courts have allowed employers in grooming cases to design rules imposed differentially according to sex. In one sex-plus case, an employer's refusal to hire a male applicant who had long hair, because the image associated with men who had long hair would harm the employer's business, was not viewed as sex discrimination. Willingham v. Macon Tel. Publishing Co., 507 F.2d 1084, 1091-92 (5th Cir. 1975) (en banc). According to the Fifth Circuit, hair length is not an immutable characteristic or fundamental right, such as the right to marry or to raise children or, presumably, the status of being Black. Indeed, Congress did not allow BFOQs for race or color discrimination. 
to choose between her race and sex claims. ${ }^{91}$ Using the sex-plus approach, the appellate court recognized that a Black woman could experience discrimination, even though Black men and white women did not, and found Black women to be a protected sub-class under Title VII. ${ }^{92}$ The court held that Congress intended the word "or" in Title VII to be additive rather than exclusive because it had refused to insert the word "solely" to modify the word "sex." not to be diluted because discrimination adversely affects only a portion of the protected class"94 of women. The court felt it important to provide the plaintiff with some way to obtain a "fair remedy" within the confines of existing Title VII analysis. Noting that Congress provided no clear indication of its intent regarding discrimination directed at Black women, the court nevertheless refused to adopt a result which would leave Black women without a viable Title VII remedy. ${ }^{95}$

The Fifth Circuit first addressed only Jefferies' race claim; it examined her sex allegations separately. Finally, the court examined her claim as that of a woman who, due to a secondary category (race), faced discrimination. The court attempted to rationalize its decision by applying an established theory that used sex as the main method of analysis and in doing so, it subordinated race to the level of a secondary factor..$^{96}$

The Jefferies majority, like the Degraffenreid court before it, failed to tailor the old remedies or create new ones to deal specifically with groups

91. In her complaint, Jefferies alleged she was discriminated against "because she is a woman, up in age and because she is Black." Jefferies, 615 F.2d at 1025. She brought a race and sex discrimination action against her employer for failing to promote her and for wrongful discharge. The district court did not explain why Jefferies' age discrimination claim was not continued.

The district court, employing the Degraffenreid approach, read the "or" in Title VII disjunctively and followed the judicial trend of addressing Black women's race and sex discrimination claims separately. The plaintiff ultimately lost her race claim because the court held that Blacks were not excluded from positions similar to the ones she applied for-one had previously been held by a Black man. Jefferies v. Harris County Community Action Ass'n, 425 F. Supp. 1208 (S.D. Tex. 1977). The court further ruled that the plaintiff did not prove the existence of sex discrimination because white women, too, had held similar positions in the past. Id. at 1213.

92. Jefferies, 615 F.2d at 1034 .

93. See supra Section II(B).

94. 615 F.2d at 1034 (quoting Sprogis v. United Air Lines, Inc., 444 F.2d at 1198).

95. Id. at 1032 .

96. Why were Black women considered a "sub-class" within a sex-plus rationale? Why didn't the court use race-plus, instead of sex-plus or just devise a "protected category-plus" test? What of Judge Brown's statement in Phillips that "[o]f course the 'plus' could not be one of the other statutory categories of race, religion, national origin, etc."? Phillips, 416 F.2d at 1260 n.10 (Brown, J., dissenting). Judge Randall felt, as she expressed in a footnote to the Fifth Circuit's opinion in Jefferies, that "this court is not in a position to decide the question whether black females are a special Title VII class and the related question concerning the effect recognition of such a subclass would have on the traditional framework of proof in Title VII cases." Jefferies, 615 F.2d at $1034 \mathrm{n.7}$. She believed that a sex-plus analysis should not apply to this case because:

[n]one of the "sex-plus" cases involves the use of two statutorily protected characteristics as the basis of employment discrimination. . . . What effect recognition of a subclass of black females should have on the traditional evidentiary framework governing Title VII litigation is simply not addressed in "sex-plus" cases.

Id. at 1035 n.7. 
more than one step removed from the white male norm. ${ }^{97}$ The sex-plus methodology forces Black women to choose gender as their principal identification ${ }^{98}$ thereby perpetuating a fundamental misunderstanding of the nature of the discrimination experienced by Black women, most of whom do not consider their race to be secondary to their sex..$^{89}$

Jefferies has had an impact on other courts, which have subsequently adopted the sex-plus rational as a framework for understanding Black women. ${ }^{100}$ However, even this incomplete concession to the reality of Black women's whole personhood has been limited by one recent case, Judge v. Marsh. ${ }^{101}$ The Jefferies sex-plus approach to understanding Black women's claims actually set the stage for Judge's limitation upon those claims.

In Judge, a Black woman employed by the United States Army alleged a Title VII violation based on race and sex. ${ }^{102}$ The court accepted the Jefferies holding that "[r]ace discrimination directed solely at women is not less invidious because of its specificity," tions against a Black woman may violate Title VII. However, the court also criticized the Jefferies language as being overbroad. The Judge court interpreted and applied the concept of "sex-plus" in a restrictive manner, concluding that "the Jefferies analysis is appropriately limited to employment decisions based on one protected, immutable trait or fundamental right, which are directed against individuals sharing a second protected, immutable characteristic." 104 Under this analysis, the Judge court allowed the plaintiff to maintain a sex-plus discrimination claim as a woman who possessed a second immutable trait-race-that contributed to her discrimination. In addition, although the plaintiff in the case was not seeking to include other pluses in her claim, the court held that a plaintiff in a Title VII case could claim only one plus, ${ }^{105}$ which for Black women would almost invariably be their race. The court sought to ensure that the sub-class would be narrowly defined so that Title VII would "not be splintered beyond use and recognition." ${ }^{108}$ Allowing additional plus fac-

\footnotetext{
97. See infra notes 111-13 and accompanying text.

98. Palmer, supra note 21 , at $152-53$.

99. See infra note 113 and accompanying text.

100. The other cases which have adopted the Jefferies explanation for allowing Black women to be considered a Title VII sub-group within a sex-plus framework include Hicks v. Gates Rubber Co., 883 F.2d 1406, 1416 n.2 (10th Cir. 1987); Judge v. Marsh, 649 F. Supp. 770, 780 (D.D.C. 1986); Chambers v. Omaha Girls Club, 629 F. Supp. 925,944 n.34 (D. Neb. 1986); and Graham v. Bendix Corp., 585 F. Supp. 1036, 1047 (N.D. Ind. 1984).

101. 649 F. Supp. 770 (D.D.C. 1986).

102. Referring to Jefferies, the court stated that "[e]xtrapolating from . . . sex-plus cases, the Fifth Circuit has determined that Black women are a distinct sub-group, protected by Title VII." Judge, 649 F.Supp. at 780.
}

103. Id.

104. Id.

105. Id.

106. Id. 
tors, the court felt, would create a "many-headed Hydra, impossible to contain within Title VII's prohibition."107 The Jefferies court, by viewing Black women within a sex-plus framework, gave the Judge court the ability to limit Black women's claims. Had the Jefferies court viewed Black women as a distinct class under Title VII, who should be given protection because sex and race are both prohibited categories, the issue of sex-plus and what constitutes a "plus" could have been avoided. Instead, the issue would have been whether persons of "like qualities [are] given employment opportunities irrespective of their sex" and race, rather than allowing the focus to shift to arbitrary sex-plus limits. ${ }^{108}$

On a practical level, the requirement of constraining "subgroups" to one plus factor is detrimental to Black women, who must use their race as the plus factor. Forcing Black women to use their single plus factor on race prevents them from fairly addressing other issues that may contribute to their discrimination. ${ }^{109}$ For example, if a Black woman wanted to allege another plus factor under Title VII, such as being pregnant, married, or single with children, ${ }^{110}$ she would have already exhausted her plus "allowance" with her race allegation. By contrast, a white woman could seek a remedy for discrimination on the basis of any of these characteristics, since her race, unlike that of a Black woman, is generally not considered to be a plus factor because of society's tendency to value "whites" over "Blacks." The more someone deviates from the norm, the more likely s/he is to be the target of discrimination. Ironically, those who need Title VII's protection the most get it the least under Judge's limitation.

Questions should also have been raised about the sex-plus theory's classification of the racial element of Black women's claims as an "other" factor and about the effect of addressing Black women's race and sex discrimination claims in the context of sex discrimination. Professor Shoben states that Jefferies' sex-plus (women-plus-Black) rationale is based upon a "single-dimension sex discrimination theory," which requires that the court ask only "if the employer's rule singled out only women among Black persons. The answer might be yes, but then only a sex discrimination claim has been established." 111 Generally, courts have not recognized

107. Id. Cf. supra text accompanying notes 85-86 (Degraffenreid court expressing concern about opening "Pandora's box" by allowing Black women to combine race and sex claims).

108. See H. Kay, TeXr, Cases and Material on SeX-Based Discrimination 491 (3rd ed. 1988) (discussing Phillips v. Martin Marietta Corp., 400 U.S. 542, 547 (1970)).

109. See infra notes 120-22 and accompanying text.

110. Id.

111. Shoben, supra note 62 , at 793,804 . Shoben argues that sex-plus does not ask the question "whether a rule against black women amounts to discrimination against a group known to be protected by [Title VII]." Id. Instead, a sex-plus approach asks whether "a rule against blackness applied only to women amounts to discrimination against women." Id. Shoben is also concerned that viewing Black women in a sex-plus framework would allow a BFOQ defense. Id. However, she indicates that this is unlikely because there is no BFOQ for race discrimination claims. Shoben contends that "[t]he comparable BFOQ for excluding black women would have to depend on a necessity for excluding blackness for women employees-a defense not permitted by the Act." Id. at 805; see 
the limitations of a sex-plus theory as applied to Black women. Sex-plus fails to conceive of Black women's full experience as a unique group. Conceptualizing Black women's experiences as "racism with sexism hooked into it [and] vice versa"112 results in an incorrect view of Black women as the sum of two parts, rather than as a whole beings. ${ }^{113}$

\section{BEyond Sex-Plus}

Given the failure of political, economic, and legal institutions to understand the problems of Black women, it is not surprising that many courts in the 1970s did not know how to handle Black women's claims and that, even today, they have yet to develop an approach that adequately deals with Black women.

\section{A. The Courts' Power to Interpret: the Scope of Title VII}

Although Black women continue to be inadequately protected by Title VII, the primary purpose of the statute, as revealed by both its legislative history and subsequent court decisions, is to eradicate "all aspects of discrimination."114 Courts have elaborated on this goal by stating that "Title VII is a remedial statute to be liberally construed in favor of the victim of discrimination."11s Courts have broad discretionary powers to interpret and apply Title VII. ${ }^{116}$

generally C. MAcKInNon, Sexual Harassment of Working Women 190-91 (1979) (commenting on sex-plus doctrine).

112. Crenshaw, supra note 1 , at 19. This additive approach to discrimination:

treats the oppression of a Black woman in a sexist and racist society as if it were a further burden than her oppression in a sexist but non-racist society, when, in fact, it is a different burden . . . [since] [t] he additive analysis also suggests that a woman's 'racial' identity can be 'subtracted' from her combined sexual and 'racial' identity.

Spelman, Theories of Race $\mathcal{E}$ Gender-The Erasure of Black Women, 5 QuesT 36, 43, 46 (1982); R. Austin, Sapphire Bound 2 (Oct. 26, 1988) (unpublished draft) (on file with Professor Austin at University of Pennsylvania).

113. A consideration of the experiences of Black women shows that they do not experience their discrimination merely as two discrete units "piled upon each other." The starting point should be that a Black woman, as a whole being - a member of a distinct class-can allege that she is being discriminated against as a "Black woman." She should not be limited to only one plus factor, especially when that factor itself explicitly falls under Title VII's protection.

114. S. Re. No. 867,88 th Cong., 2 d Sess. 10 (1964).

115. Robinson v. Adams, 830 F.2d 128, 132 (9th Cir. 1987) (citing Mahroom v. Hook, 563 F.2d 1369, 1375 (9th Cir. 1977), cert. denied, 436 U.S. 904 (1978)). Griggs v. Duke Power Co., 401 U.S. 424 (1971), shaped "the statutory concept of 'discrimination' in light of the social and economic facts of our society . . . [by applying a] sensitive, liberal interpretation of [T]itle VII." Blumrosen, Stranger in Paradise: Griggs v. Duke Power Co. and the Concept of Employment Discrimination, 71 Mich. L. REv. 59, 62-63 (1972). Griggs stated that Congress, in passing Title VII, required courts to remove all artificial, arbitrary, and unnecessary barriers to employment "that operate invidiously to discriminate on the basis of racial or other impermissible classifications." 401 U.S. at 431.

116. Blumrosen, supra note 115 , at 73 . Congress sought "to provide a legal solution to a complex problem and uniformly left many problems including the definitional problems" to the agencies and courts. Id. at 67 . 


\section{B. Acknowledging Competing Visions of Reality}

The history of Black women, the current levels of poverty and unemployment which they experience, and the special problems they encounter in the workplace indicate that they occupy a unique position in American society. To resolve the inequities that confront Black women, courts must first correctly conceptualize them as "Black women," a distinct class protected by Title VII. Courts should reject the Jefferies conception of Black women as a "sub-class" under either a "sex-plus" or "race-plus" analysis because neither adequately encompasses Black women's experiences.

Once Black women are conceptualized correctly, courts must also become sensitive to Black women's unique historical, social, and economic experiences in the United States. ${ }^{117}$ Courts should draw upon Black women's experiences and perspectives when reaching decisions concerning Black women. ${ }^{118}$ Black women's history and point of view must also become documented in judges' decisions; these decisions should reflect an understanding of the law's impact on Black women, just as the experiences of white women and Black men were acknowledged in the Supreme

117. Employment discrimination is harder to prove today because it is more subtle and sophisticated, taking the form in many cases not of intentionally discriminatory acts, but appearing in "well established practices and customs." Haywood, supra note 44, at 19, 33. For example, certain promotion systems, career ceilings, stereotyping, job assignment plans, and examinations seem fair in form, but in practice they encourage discrimination. Id.; B. RESKIN \& H. HARTMANN, WOMEN'S WORK, MEN's WORK-SEx SEgREgation ON THE JoB (1986) (discussing subtle types of discrimination faced by women); R. FARLey, Blacks AND WhItes: Narrowing the GaP 57-81, 198 (1984) (addressing discrimination Blacks face and its impact on wage differential between Blacks and whites in America).

Studies analyzing the effects of subtle and sophisticated employment discrimination on Black women are scarce; courts are not the only ones who have thought of Black women as being dealt with under the broad terms of "Blacks" and "women." However, one can begin to understand the effect of race-sex discrimination on Black women by examining the small existing literature concerning Black women. Professor Ellis describes the effect of race-sex discrimination against Black women in sexual harassment cases. Ellis, supra note 15, at 39. Malveaux and Wallace describe the existence of "black women crowding" and explain the position of black women in society, revealing that black women are subject to race-sex discrimination which effects them differently than Black men and white women. Malveaux \& Wallace, supra note 53.

Courts must expand the scope of Title VII to address the concerns of Black women. For example, an extension of Title VII disparate impact theory to pay discrimination claims would address the specific problems of Black women who are crowded into the lowest paying and lowest status jobs. See supra notes 49-59 and accompanying text. While the statutory language does not specify that wage differential claims can be brought under Title VII, allowing such claims would be consistent with the broad scope courts have given to Title VII. Title VII "was intended to be broadly inclusive, proscribing, not only overt discrimination but also practices that are fair in form, but discriminatory in operation." Haywood, supra note 44 , at 34 n.99.

118. See generally J. Culp, A Black Perspective on the Law and Economics of Title VII: Judicial Discretion and Discrimination 1 (1989) (unpublished manuscript) (on file with Professor Culp at Duke University). According to Professor Culp, all "judicial interpretation requires some framework that judges use in reaching their decisions." Id. at 11 . However, the problem with the current legal interpretation is that Black people's perspectives have not been used by judges in making their decisions. Id. at 12. Professor Culp argues that "race matters in American legal discussion," id. at 14, and that judges must recognize competing visions of reality in order for all people to be able to obtain justice: "For [a] society that lets the 'haves' define all of the choices is only fair if our initial distribution of rights and goods are in fact appropriate from a social justice standpoint." Id. at 50; Minow, supra note $88,10-11$. 
Gourt's Frontiero opinion. ${ }^{119}$ This documentation will make the experience of Black women in the American legal system visible, in addition to revealing the importance of viewing Black women as a class "of and unto themselves," who face different problems, often having distinct concerns requiring solutions different from those prescribed for Black men and white women.

\section{G. "Black Women" and Non-Statutory Factors}

One of the potential harms that Black women face as a result of the Jefferies decision is that some courts may be persuaded by the Judge $v$. Marsh interpretation of the Jefferies sex-plus approach and allow Black women to use their race as the only "plus" factor. ${ }^{120}$ However, under the approach proposed by this Note, if a Black woman with children or a foreign accent brought a race-sex discrimination claim, her race would not be seen as a plus factor; in fact, no category explicitly protected by Title VII could be considered a plus factor. She would be thought of as a Black woman, a member of a separate class fully covered by Title VII. If any factor were to be considered a "plus," it would be her status as, for example, a parent. Thus, this Note proposes, in order to ensure that employers are not allowed to discriminate against people because they are married, have children, or speak with an accent, that the "plus" concept be used by

119. See supra text accompanying notes 38-39.

120. See supra notes $102-07$ and accompanying text. But see Chambers v. Omaha Girls Club, 629 F. Supp. 925, 944 n.34 (D. Neb. 1986), decided before Judge, in which a court upheld the firing of an unmarried pregnant Black woman because she was setting a negative role model for the Girls Club teenage members. The court allowed a "sub-class" of women-Black women-to bring a claim that alleged that their "sub-group" would be discriminated against because of an employer's rule which prohibited unmarried women from becoming pregnant. Id. at 943 . The court was able to handle three factors without falling victim to the "many-headed Hydra impossible to contain within Title VII's prohibition" and so feared by the Judge court. Judge, 649 F. Supp. at 780 . Despite the negative outcome of Chambers, this decision indicates that if a court is able to handle two protected characteristics and an additional plus factor it can handle three or more characteristics protected by Title VII in multi-factor employment discrimination claims, provided that there is an adequate population to make a disparate impact determination possible.

Despite its attempt at managing several factors, the Chambers court failed to take into consideration the realities of Black women's perspectives. When it assessed the employer's concerns, it utilized a particular value system without recognizing the effect that such a decision would have upon Black women. As Professor Austin states in Sapphire Bound, the Chambers court failed to take into consideration the perspective of Black women and instead applied its "white and middle class values" to the case. See Austin, supra note 112, at 28. In Austin's views the bottom line of this case is that "unmarried black women who have babies are essentially being accused of carrying on like modern-day Jezebels when they should be acting like good revisionist Mammies." Id. at 50. The Club's policy of firing a pregnant Black woman because she is unmarried had negative economic effects on her. The decision imposed "a marriage requirement as a condition for working with black youngsters [which] adds to the burden that single black pregnant women and mothers already bear in the name of patriarchy, i.e., the supremacy of the male as the head of the family unit," and penalized Black women economically if they failed to adhere to such requirements. Id. at 44 .

It is not enough for courts only to change how they view Black women. As Minow states, judges must be aware that their perspectives are only one of many competing views. Minow, supra note 88, at 33. Title VII should be utilized by judges in a manner which is free of them imposing their own perspective to the exclusion of others. They must also recognize their own tendencies toward racial and sexual stereotyping. 
courts to take into consideration discrimination based upon factors which are not explicitly protected by Title VII. ${ }^{121}$ This category-plus approach $^{122}$ aims to ensure that Title VII is applied to Black women in the same way that it has been applied to "Blacks" and "women."

\section{Title VII Multi-Factor Claims-A Holistic Approach}

Clearly, recognizing Black women as a protected class under a multifactor Title VII approach will have implications for other groups facing discrimination, including "Asian women," "Puerto Rican men," and "Ethiopian Jewish women." These groups may have distinct histories, socio-economic situations, and/or a unique current workplace experience, all of which should be recognized by the law so that each group concerns can be understood based upon their own experiences, rather than based upon how much they deviate from the white male norm. ${ }^{123}$ Courts that are willing to allow other groups' race-sex claims, based upon the same principles as Black women's race-sex claims, may be uncomfortable recognizing that Title VII claims can be based upon as many as three, four, or five of the protected categories-race, color, religion, sex, and national origin. Professor Minow observes that when those in the mainstream attempt to deal with people who are "many steps away from the norm," the complexity of the situation "seems both overwhelming and incapacitating" because "[b]y bearing into complexity rather than turning away from it, by listening to the variety of voices implicated in our problems, we may lose a sense of ready solutions and steady certainties." ${ }^{124}$ Some courts may argue that adopting a multi-factor approach is tantamount to special treatment for Black women and may result in the creation of a "many headed-

121. See Morris, Stereotypic Alchemy: Transformative Stereotyping and Anti-discrimination Law 6 YALE L. Rev. \& POL'Y REv. — (forthcoming 1989) (addressing claims brought by overweight people, people with accents, etc.).

122. The category can be any of Title VII's listed factors. See supra note 5.

123. Such an approach might also have implications for Black men. One court denied a Black man's claim that he was being discriminated against as a Black man. In Robinson v. Adams, 830 F.2d 128 (9th Cir. 1987), the plaintiff alleged that he was discriminated against as a Black man. The defendant, Orange County, did not have any Black male employees. However, Black female employees comprised $1.7 \%$ of the Superior Court workforce and $2.7 \%$ of both the "Professional" and "Official/Administration" positions in Orange County. Id. at 131. The court held:

Obviously, since Blacks are not statistically underrepresented in the Orange County Superior

Court's work force, Robinson cannot plausibly maintain that the Court's hiring practices have a racially discriminatory impact on Blacks as a whole. . . . His showing that Black males are statistically underrepresented cannot, standing alone, show a racially discriminatory impact ... on Blacks as a whole. The only relevant statistic concerning Blacks, the protected class of which Robinson is a member, indicates that $1.7 \%$ of the Superior Court employees were black. Id. at 131 .

Judge Pregerson dissented, stating that "Robinson has raised a genuine issue of material fact on whether blacks and particulary black males are proportionally represented in the court's work force." Id. at 133. The Robinson majority simply could not see how race and sex could interact to produce a plurality of stereotypes and concomitant patterns of discrimination against Black men. Thus, Black men could also benefit from a more holistic approach to Title VII claims.

124. Minow, supra note 88 , at 82 . 
Hydra."125 For the sake of simplicity, some may argue, the concerns of individuals who face discrimination based on more than two of the listed characteristics must be sacrificed because such people are too "weird," or too far removed from the white-male-Christian norm. Should the experiences of a Jamaican Black woman who faces discrimination as a result of her nationality, race, and sex be ignored because of Judge's arbitrary and artificial limitations? Courts should not be satisfied with extending Title VII's protection only to American-born Black women, but should also reach out to Jamaican Black women. In addition, a Black woman with dark skin, who is being discriminated against because of her race, sex and color, could not bring this type of discrimination claim because she would exceed her plus allowance. Should this person's concerns be ignored? Evidentiary and administrative complications cannot justify such a limitation. Judge's artificial limitations make no sense, particularly in light of the Chambers decision, where the court allowed an unmarried pregnant Black woman to bring a discrimination claim, and the clear aim of Title VII. ${ }^{126}$

Courts should also rethink how much justice they are willing to sacrifice for the sake of simplicity. Society "needs a setting in which to engage in the clash of realities that breaks us out of settled and complacent meaning and creates opportunities for insight and growth. This is the special burden and opportunity for the court: to enact and preside over the dialogue through which we remake the normative endowment that shapes current understanding."127 Even when considering multi-factor cases brought by individuals, for whom there may not be a statistically relevant comparison group (e.g., Ethiopian Jewish Black women), courts must ask whether the present application of the discriminatory impact/intent theories is the only acceptable approach for recognizing discrimination. ${ }^{128}$

125. See supra text accompanying note 107 .

126. See supra note 120 . In addition, Judge's interpretation of the sex-plus test created by the dissent in Phillips v. Martin Marietta is incorrect. The focus should be on whether an individual was treated differently from other persons because of any characteristic protected by Title VII, not whether the plaintiff has exceeded her arbitrarily imposed sex-plus allowance. Clearly, if a plaintiff can prove discriminatory intent, based upon any of Title VII's protected factors, s/he should not be denied relief because a showing of clear intent would make denial of such a claim illogical. Some may argue that although an individual's multi-factor claim under an intent theory might be viable, a multifactor claim cannot be considered under a discriminatory impact theory if an individual is part of a group that is statistically so small that no valid comparison can be made. However, this is not always the case. If a Jamaican Black woman sought to bring a discrimination case based upon her race, sex, and nationality in the New York City area, where her group forms a sizable population, there would be no reason to prohibit her from bringing a multi-factor claim if that claim indeed reflected the discrimination she had experienced.

127. Lawrence, The Id, The Ego, And Equal Protection: Reckoning With Unconscious Racism, 39 Stan. L. Rev. 317, 386 (1987). Professor Lawrence also points out that the "victim's perspectives" must be heard so that courts can become a legitimate forum for normative debate. Similarly, Minow argues that judges must recognize that their opinions are only one point of view, and that other points of view and realities exist. Minow, supra note 88 , at 15,81 .

128. Professor Lawrence has proposed a "cultural meaning" test to be used by judges in equal protection cases to help them recognize race-based discriminatory acts-especially unconscious racially discriminatory acts. Lawrence, supra note 127, at 324, 331-39, 387. This approach would require courts-like cultural anthropologists-to consider historical and social context in order to determine 
Courts must reconsider whether it is "just" to ignore these people's pains, concerns, and voices-their realities-particularly since the aim of Title VII is to eliminate all forms of discrimination based on race, color, sex, religion or national origin.

\section{CONCLUSTON}

As Black women's historical, social, and economic experiences illustrate, courts must begin to adopt fairer and more consistent anti-discrimination policies-ones that view people within the true context of their present realities and historical experiences and allow their claims to be effectively addressed. By conceptually redefining Black women and adopting a liberal interpretation of Title VII, courts will more properly fulfill Congress' mandate to eliminate employment discrimination and will begin to grant Black women and others the legal recognition they have historically been denied. ${ }^{129}$

whether they should apply heightened scrutiny. Id. at 356.

129. Despite this Note's proposal, Title VII is still limited in that it only helps Black women who have jobs or who can make discriminatory hiring claims. Therefore, Black women must continue, despite the negative climate, to push for aggressive affirmative action policies, comparable worth, and other "broader affirmative action tactics to address all of the concerns of black women." Malveaux, supra note 54, at 60. See C. Rutherford, Employment-Redressing the Oversight, Address given at The First Conference on Women of Color and the Law, sponsored by The Collective on Women of Color and the Law at Yale (Apr. 16, 1988); see generally Panel, Employment: Empowerment in the Workforce, Address given at the Second Conference on Women of Color and the Law, sponsored by the NYU Review of Law and Social Change (Nov. 1, 1988). 